\title{
UPAYA MENINGKATKAN HASIL BELAJAR IPS MELALUI MODEL PEMBELAJARAN CIRCUIT LEARNING PADA SISWA KELAS V
}

\author{
Oktafina Bikhurin'in, Asma'ul Husna, Fitria Martanti
}

\author{
Fakultas Agama Islam Universitas Wahid Hasyim Semarang \\ oktafinabikhurinin@gmail.com
}

\begin{abstract}
Abstrak
Penelitian tindakan kelas ini bertujuan untuk meningkatkan hasil belajar siswa khususnya mata pelajaran IPS melalui model pembelajaran circuit learning. Penelitian ini merupakan penelitian tindakan kelas yang dilaksanakan di MI Wonoyoso Pringapus kecamatan Pringapus Kabupaten Semarang dengan subjek penelitian yaitu siswa kelas $V$ yang berjumlah 16 siswa, terdiri dari 12 siswa laki-laki dan 4 siswa perempuan. Penelitian dilaksanakan dalam 2 siklus, setiap siklus penelitian terdiri dari tahap perencanaan, pelaksanaan, observasi, dan refleksi. Teknik pengumpulan data menggunakan tes, observasi, dan wawancara. Hasil penelitian sebagai berikut: kondisi awal pra siklus menunjukkan bahwa rata-rata hasil belajar siswa yaitu 33,4 dan belum ada siswa yang tuntas mencapai nilai KKM (70), siklus I nilai rata-rata hasil belajar meningkat 45,9 dengan ketuntasan klasikal 6,2\% karena hanya 1 siswa yang tuntas mencapai KKM (70), dan pada siklus II nilai rata-rata hasil belajar meningkat lagi dengan rata-rata hasil belajar 83,1 dan ketuntasan klasikal mencapai 81,2\% sehingga penelitian ini dikatakan berhasil. Berdasarkan perolehan tes formatif yang terus mengalami peningkatan tiap siklus tersebut, dapat disimpulkan bahwa hasil belajar IPS dapat ditingkatkan melalui penggunaan model circuit learning pada siswa kelas V MI Wonoyoso Pringapus.
\end{abstract}

Kata Kunci: Hasil Belajar, IPS, Model Pembelajaran Circuit Learning

Abstract

The goal of this classroom action research is to improve the students learning result especially on IPS lesson through circuit learning model. This research is classroom action research which conducted in MI Wonoyoso Pringapus, kecamatan Pringapus, Kabupaten Semarang and the subjects are 16 students of fifth grade, consist of 12 male students and 4 female students. This research conducted in 2 cycles, each cycle consist of planning, implementation, observation and reflection. Technique of data collection using test, observation, and interview. The result of this research as follow : early condition before cycle show that the average of students' learning result was 33,4 and no one reached the completeness (70), cycle 1 the average score of learning result increased become 45,9 with classical completeness $6,2 \%$ because only one student reached the completeness (70), and on cycle 2 the average score increased again with the learning result was 83,1 and classical completeness until $81,2 \%$ and this research can be said success. Based on the test formative result which always increase in every cycle, can be concluded that the learning result of IPS 
can be increased by the use of circuit learning model for fifth grade in MI Wonoyoso Pringapus.

Keywords : learning result, IPS, circuit learning model

\section{A. PENDAHULUAN}

Dewasa ini sudah menjadi kelaziman bahwa proses pembelajaran dipandang sebagai aspek pendidikan jika berlangsung di sekolah. Hal ini menunjukkan bahwa proses pembelajaran merupakan proses yang mendasar dalam aktivitas pendidikan di sekolah, sehingga dari proses pembelajaran tersebut siswa memperoleh hasil belajar yang berupa nilai-nilai dan keterampilan tertentu. Hasil belajar yang baik akan diperoleh melalui proses yang baik, dan proses belajar yang baik akan memberikan hasil belajar yang baik pula.

Ilmu Pengetahuan Sosial merupakan salah satu mata pelajaran di SD/MI yang mengkaji seperangkat peristiwa fakta, konsep, dan generalisasi yang berkaitan dengan isu sosial. ${ }^{1}$ Pada jenjang SD/MI mata pelajaran IPS memuat materi Geografi, sejarah, sosiologi dan ekonomi. IPS di SD/MI harus memperhatikan kebutuhan anak yang berusia 6 -12 tahun. Menurut Piaget anak dalam usia 7-11 tahun berada dalam perkembangan kemampuan intelektual/kognitifnya pada tingkatan operasional kongkret. ${ }^{2}$ Guru pengampu IPS harus dapat memanfaatkan materi-materi pada mata pelajaran tersebut, selain itu yang masih menjadi hambatan selama ini adalah kurang dikemasnya pembelajaran IPS dengan metode yang menarik, menantang dan menyenangkan.

Berdasarkan wawancara dengan guru kelas $\mathrm{V}$, beliau mengungkapkan hasil belajar IPS kelas V tergolong rendah di bawah KKM (70). ${ }^{3}$ Salah satu indikator rendahnya hasil belajar siswa kelas V di MI Wonoyoso Pringapus ini adalah kurangnya keaktifan siswa dalam mengikuti kegiatan belajar mengajar mata pelajaran

\footnotetext{
hlm. 51 .

${ }^{1}$ Rudy Gunawan, Pendidikan IPS filosofi, Konsep, dan Aplikasi, Bandung: Alfabeta, 2013,

2 Desmita, Psikologi Perkembangan Peserta Didik, Bandung: Remaja Rosydakarya, 2014, hlm 101

${ }^{3}$ Fatmawati, Guru kelas V MI Wonoyoso Pringapus, Wawancara, tanggal 3 April 2018, jam 06.35 WIB
} 
IPS. Hal ini ditambah dengan fakta bahwa proses pembelajaran yang dilaksanakan di MI Wonoyoso Pringapus menggunakan paradigma lama yaitu guru sering sekali menerapkan metode konvensional atau ceramah dan penugasan dalam proses pembelajaran. Hasil observasi awal yang peneliti lakukan ditemukan masih kurangnya keinginan siswa untuk mendengarkan uraian guru, kurangnya motivasi belajar untuk berdiskusi dan mencatat pelajaran. Terkait belum optimalnya hasil belajar IPS siswa kelas V MI Wonoyoso Pringapus, maka peneliti mencoba menerapkan pembelajaran dengan menggunakan model pembelajaran yang mengacu pada proses pembelajaran berpusat pada siswa. Salah satu cara yang dapat dilakukan oleh peneliti untuk memudahkan siswa dalam belajar dan untuk membuat siswa lebih aktif dalam belajar, model pembelajaran yang digunakan yaitu model pembelajaran circuit learning.

Model pembelajaran circuit learning adalah pembelajaran dengan memaksimalkan pemberdayaan pikiran dan perasaan dengan pola bertambah dan mengulang. Guru dapat dengan mudah menyampaikan materi pelajaran dengan menggunakan peta konsep, dengan menggunakan peta konsep siswa dapat menalar sendiri dan menemukan daya kreativitasnya untuk menghubungkan pembelajaran dengan lingkungan sekitar siswa, sehingga aktivitas siswa dalam pembelajaran dengan menggunakan model ini meningkat serta siswa dapat berlatih belajar mandiri, aktif dan kreatif. Model pembelajaran ini menekankan belajar dalam kelompok heterogen saling membantu satu sama lain, bekerja sama menyelesaikan masalah dalam menyatukan pendapat untuk memperoleh keberhasilan yang optimal baik kelompok maupun individu. Pembuatan peta konsep dalam pembelajaran mempermudah siswa memahami materi IPS yang banyak dan membutuhkan hafalan untuk memahaminya secara ringkas.

Berdasarkan latar belakang di atas maka peneliti tertarik untuk mengadakan penelitian dengan judul "Upaya Meningkatan Hasil Belajar IPS Melalui Model Pembelajaran Circuit Learning Pada Siswa Kelas V MI Wonoyoso Pringapus kabupaten Semarang tahun 2017/2018 


\section{B. LANDASAN TEORI}

\section{Pengertian Model Circuit Learning}

Menurut Moch. Agus Krisno Budiyanto pengertian model pembelajaran circuit learning adalah pembelajaran dengan memaksimalkan pemberdayaan pikiran dan perasaan dengan pola bertambah dan mengulang. ${ }^{4}$ Aris Shoimin mengungkapkan pengertian model pembelajaran circuit learning adalah memaksimalkan dan mengupayakan pemberdayaan pikiran dan perasaan dengan pola bertambah dan mengulang. ${ }^{5}$ Berdasarkan pendapat di atas, peneliti menyimpulkan model pembelajaran circuit learning adalah model pembelajaran yang melatih pikiran dengan mencatat materi yang telah dipelajari atau dipahami ke dalam peta kosep, sehingga dapat mudah dipahami dan diingat.

Kitab Ta'limul Mutaalim menjelaskan tentang mengulang pembelajaran:

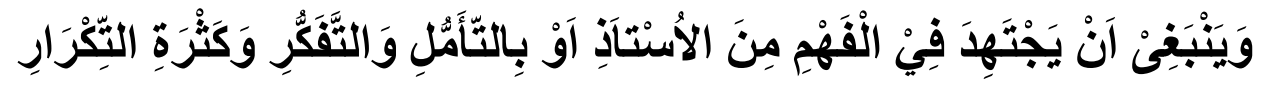

Artinya: "Seyogyanya santri berusaha sungguh-sungguh memahami apa yang diterangkan oleh gurunya. Kemudian diulang-ulang sendiri beberapa kali”. 6

Salah satu ciri-ciri model pembelajaran circuit learning adalah peta konsep. Peta konsep merupakan suatu skema atau ringkasan dari hasil belajar dengan memaksimalkan pikiran siswa. Peta konsep merupakan teknik mencatat yang memanfaatkan keseluruhan otak dengan menggunakan citra visual dan prasarana grafis lainya untuk membentuk kesan yang lebih dalam. Siswa dapat menggambarkan konsep suatu materi pelajaran dengan kreativitasnya sendiri baik segi bahasa maupun simbol-simbol yang digunakan dengan memperhatikan aturan-aturan dan notasi-notasi yang ada.

\footnotetext{
${ }^{4}$ Moch. Agus Krisno Budiyanto, Sintaks 45 Metode Pembelajaran dalam Student Centered Learning(SCL), Malang: Universitas Muhammadiyah Malang, 2016, hlm. 102.

${ }^{5}$ Aris Shoimin, 68 Model Pembelajaran Inovatif dalam Kurikulum 2013, Yogyakarta: Ar-Ruzz Media, 2014, hlm. 35.

${ }^{6}$ Syaikh az-Zarnuji, Terjemah Ta'lim Muta'alim, Surabaya: Mutiara Ilmu, 2012, hlm. 59
} 
Langkah-langkah model circuit learning menurut Miftahul Huda sebagai berikut:

Persiapan:

1) Melakukan apersepsi

2) Menjelaskan tujuan pembelajaran yang harus dicapai oleh siswa dalam pembelajaran hari ini.

3) Menyampaikan cakupan materi dan penjelasan uraian kegiatan.

Kegiatan Inti:

1) Melakukan tanya jawab tentang topik yang dibahas

2) Menempelkan gambar tentang topik tersebut di papan tulis

3) Mengajukan pertanyaan tentang gambar yang ditempel

4) Menempel peta konsep yang telah dibuat

5) Menjelaskan peta konsep yang telah di tempel

6) Membagi siswa menjadi beberapa kelompok

7) Memberikan lembar kerja kepada setiap kelompok

8) Menjelaskan bahwa setiap kelompok harus mengisi lembar kerja siswa dan mengisi bagian dari peta konsep sesuai dengan bahasa mereka sendiri.

9) Menjelaskan bahwa bagian peta konsep yang mereka kerjakan akan dipresentasikan

10) Melaksanakan presentasi bagian peta konsep yang telah dikerjakan

11) Memberikan penguatan berupa pujian atau hadiah atas hasil presentasi yang bagus serta memberikan semangat kepada mereka yang belum dapat pujian atau hadiah untuk berusaha lebih giat lagi

12) Menjelaskan kembali hasil diskusi siswa tersebut agar wawasan siswa menjadi lebih kuat.

Penutup:

1) Memancing siswa untuk membuat rangkuman

2) Melakukan penilaian terhadap hasil kerja siswa ${ }^{7}$

Menurut Miftahul Huda dalam pelaksananaanya, model pembelajaran circuit learning memiliki kelebihan dan kekurangan, diantara kelebihanya adalah:

a. Meningkatkan kreativitas siswa dalam merangkai kata dengan bahasa sendiri.

b. Melatih konsentrasi siswa untuk fokus pada peta konsep yang disajikan oleh guru.

\footnotetext{
${ }^{7}$ Miftahul Huda, Model- Model Pengajaran dan Pembelajaran, Yogyakarta: Pustaka Pelajar, 2014, hlm. 312.
} 
Kekurangan model circuit learning adalah:

a. Penerapan model ini memerlukan waktu yang relatif lama

b. Tidak semua pokok bahasan bisa disajikan dengan peta konsep. ${ }^{8}$

\section{Hasil Belajar}

Hasil belajar adalah perubahan tingkah laku siswa yang terjadi berdasarkan pengalaman belajar. Pengalaman belajar yang dimaksud yaitu saat proses kegiatan belajar mengajar yang menitikberatkan pada pengalaman belajar bermakna serta memberikan kesan kepada peserta didik. Hasil belajar bisa berbentuk pengetahuan, keterampilan maupun sikap.

Menurut Dimyati ciri-ciri hasil belajar ada tiga: (1) hasil belajar memiliki kapasitas berupa pengetahuan, kebiasaan, keterampilan, sikap, citacita, (2) adanya perubahan mental dan perubahan jasmani, (3) memiliki dampak pengajaran dan dampak pengiring. Ketiga ciri tersebut harus diamati dalam pelaksanaan pembelajaran karena ketiga hal tersebut yang akan mempengaruhi hasil belajar yang akan diperoleh siswa. ${ }^{9}$

Berhasil atau tidaknya seseorang dalam belajar disebabkan beberapa faktor yang mempengaruhi hasil belajar. Faktor-faktor yang mempengaruhi hasil belajar adalah faktor internal dan faktor eksternal. Faktor internal berasal dari dalam diri siswa dan bersifat biologis, sedangkan faktor eksternal adalah faktor yang sifatnya dari luar diri siswa. Kedua faktor tersebut saling mempengaruhi dalam proses belajar individu sehingga menentukan kualitas belajar.

\section{Mata Pelajaran IPS}

\footnotetext{
${ }^{8}$ Miftahul Huda, Model- Model Pengajaran dan Pembelajaran, Yogyakarta: Pustaka Pelajar, 2014, hlm. 313

${ }^{9}$ Dewa ayu puspa, Pengaruh Model Pembelajaran Circuit learning Berbantu Media Audio Visual Terhadap Hasil Belajar IPS siswa SD Negeri 1 Pejeng Tahun 2013/2014, Jurnal Mimbar PGSD Universitas Pendidikan Ganesha Jurusan PGSD, (vol :2 No: 1 tahun 2014).
} 
IPS juga memiliki peranan penting dalam dunia pendidikan. Ilmu Pengetahuan Sosial merupakan salah satu mata pelajaran di SD/MI yang mengkaji seperangkat peristiwa fakta, konsep, dan generalisasi yang berkaitan dengan isu sosial. ${ }^{10}$ Ruang lingkup pembelajaran IPS di tingkat Sekolah Dasar dibatasi sampai gejala dan masalah sosial kehidupan sehari-hari yang ada pada lingkungan hidup siswa SD/MI.

Mulai dari ruang lingkup gejala dan masalah kehidupan yang ada di sekitar tempat tinggal dan sekolah, kemudian di tingkat desa, kecamatan, kabupaten, provinsi, negara dan akhirnya ke negara-negara tetangga terutama yang berkenaan dengan hubungan kerjasama ekonomi, sosial, dan budaya di wilayah-wilayah yang bersangkutan. ${ }^{11}$

\section{METODE PENELITIAN}

Penelitian ini merupakan penelitian tindakan kelas (PTK). Desain penelitian tindakan yang digunakan adalah model siklus yang dikembangkan oleh Kemmis dan Mc. Taggart. Desain siklus PTK sebagai berikut: ${ }^{12}$

${ }^{10}$ Rudy Gunawan, Op. Cit hlm. 51

${ }^{11}$ Solihatin, Cooperative Learning Analisis Model Pembelajaran IPS, Jakarta: Bumi Aksara, 2005, hlm. 15 .

${ }^{12}$ Suharsimi Arikunto, Suhardjono, Supardi, Penelitian Tindakan Kelas, Jakarta: PT Bumi Aksara, 2015, hlm. 144. 


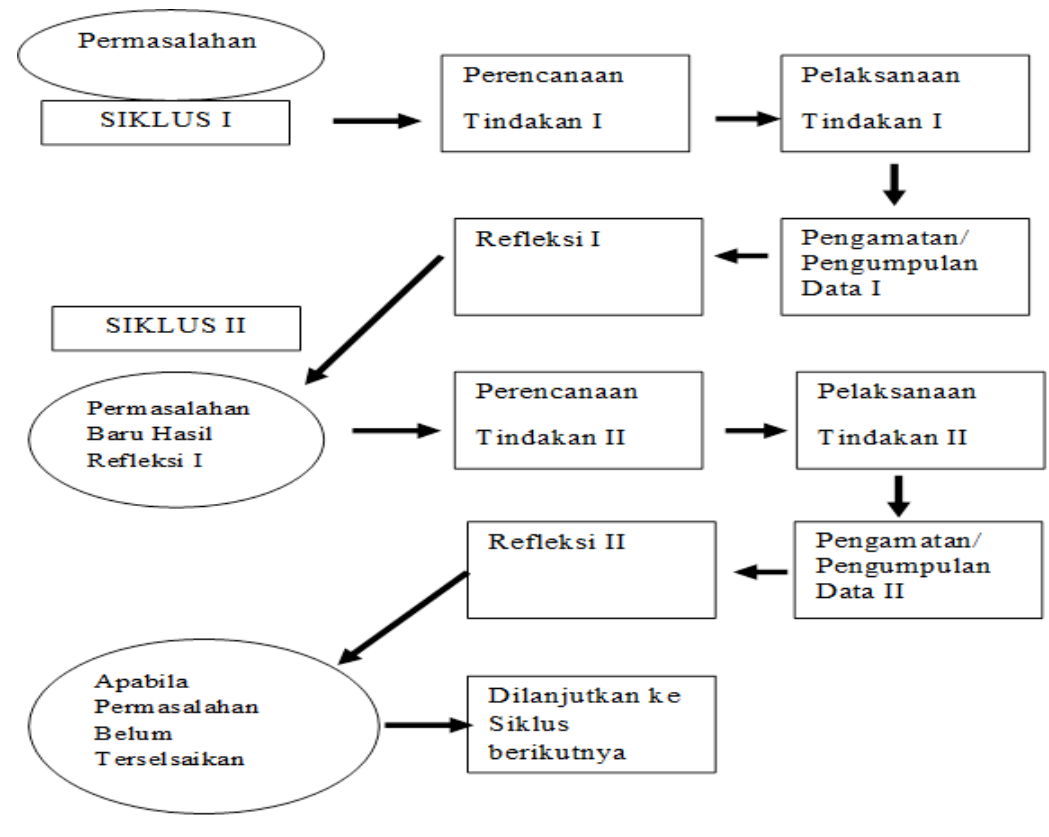

Gambar 1. Skema Desain Penelitian Tindakan Kelas menurut Kemmis dan Mc Taggart

Secara garis besar terdapat empat tahapan sebagai berikut:

a. Menyusun rencana tindakan

Menentukan materi pokok, membuat RPP, menyiapkan sarana, media dan model pembelajaran yang akan diterapkan selama penelitian berlangsung, lembar observasi dan lembar kerja siswa serta membuat pedoman wawancara.

b. Pelaksanaan tindakan

Urutan kegiatan yang akan dilakukan pra siklus, siklus I dan siklus II.

c. Pengamatan

Kegiatan ini dilakukan bersamaan dengan pelaksanaan tindakan, jadi selama pelaksanaan tindakan, peneliti juga melakukan pengamatan selama proses pembelajaran berlangsung sambil mengumpulkan data-data yang diperlukan seperti catatan, dokumentasi dan lembar kerja siswa. 


\section{d. Refleksi}

Melakukan kegiatan pengamatan, perenungan suatu tindakan dan melakukan alternatif-alternatif solusi dari permasalahan yang timbul selama pelaksanaan tindakan.

Penelitian ini dilaksanakan di kelas V MI Wonoyoso Pringapus. Subjek penelitian ini adalah seluruh siswa kelas $\mathrm{V}$ yang berjumlah 16 orang siswa, terdiri dari 12 siswa laki-laki dan 4 orang siswa perempuan. Metode Analisis yang digunakan adalah:

a. Data Kuantitatif berupa hasil belajar siswa pada pembelajaran IPS khususnya pada ranah kognitif yang diperoleh melalui tes isian singkat dan uraian.

b. Data kualitatif yaitu data aktivitas guru dan siswa dalam pembelajaran IPS.

Teknik Analisis Data yang digunakan dengan data kuantitatif diolah dan dinyatakan dalam bentuk presentase yang dihitung menggunakan rumus sebagai berikut:

1) Menghitung Mean/ Rerata Kelas

$$
\mathrm{X}=\frac{\Sigma N}{\Sigma S}
$$

Keterangan:

$\mathrm{X}=$ nilai rata- rata tes formatif

$\Sigma \mathrm{N} \quad=$ jumlah semua nilai siswa

$\Sigma \mathrm{S} \quad=$ jumlah siswa

2) Menghitung Presentase Ketuntasan belajar klasikal menggunakn rumus sebagai berikut:

$$
\text { Ketuntasan klasikal }=\frac{\sum \text { siswa yang tuntas }}{\sum \text { seluruh siswa }} \times 100 \%
$$




\section{HASIL PENELITIAN DAN PEMBAHASAN}

\section{Hasil Penelitian}

a. Hasil Belajar

1) Pra Siklus

Tahap pra siklus ini dilakukan sebelum peneliti menggunakan model pembelajaran circuit learning. Hasil belajar siswa pada tahap pra siklus ini tergolong masih rendah. Hal ini terbukti dari nilai pra siklus tidak ada satupun siswa yang mencapai nilai KKM (70). Tahap pra siklus ini hasil belajar 16 siswa mencapai rata-rata yaitu 33,4. Siswa pada tahap ini tidak memperhatikan guru saat menyampaikan tujuan pembelajaran, mereka asyik berbicara sendiri dengan teman sebangkunya. Hal itu dikarenakan masih digunakanya metode konvensional oleh peneliti, yaitu metode ceramah.

2) Siklus I

Tahap siklus I ini diperoleh data hanya satu siswa yang tuntas dari 16 jumlah siswa dengan presentase ketuntasan klasikal mencapai 6,3\% dan hasil rata-rata hasil belajar adalah 45,9. Aktivitas siswa yang diharapkan peneliti yaitu siswa dapat membuat catatan kreatif dengan bahasa khusus, peta konsep, bertanya dan menjawab pertanyaan. Hasil tersebut bila dibandingkan dengan nilai hasil belajar rata-rata pra siklus yaitu 33,4, terdapat peningkatan setelah menerapkan pembelajaran dengan model pembelajaran circuit learning, meskipun ketuntasan belum mencapai $75 \%$ sesuai harapan peneliti, sehingga peneliti perlu melanjutkan tindakan ke siklus II.

3) Siklus II

Tahap siklus II ini diketahui bahwa terdapat 13 siswa dari 16 siswa tuntas dengan prosentase ketuntasan klasikal $81,1 \%$ dan hasil ratarata yaitu 83. Hal ini tidak terlepas dari kreasi dan kreatif guru dalam menerapkan model pembelajaran ini, diantaranya untuk 
mempermudah siswa membuat peta konsep dibantu oleh guru dengan menambah media yang digunakan dalam proses pembelajaran, dan untuk mempermudah siswa membuat catatan kreatif dan bahasa khusus, guru membimbing siswanya dengan memberikan arahan dan petunjuk dengan bahasa yang mudah dimengerti oleh peserta didik. Langkah guru untuk menghindari kejenuhan, kebosanan guru mengubah pola tempat duduk siswa. Tahap siklus II ini menunjukkan pencapain tujuan pembelajaran dan hasil belajar sudah memenuhi indikator keberhasilan yang di tentukan.

Hasil belajar pada penelitian ini menitikberatkan pada hasil belajar yang berupa kognitif. Hasil belajar kognitif diukur melalui tes dan dari nilai yang diperoleh. Hasil belajar kognitif berkaitan dengan penguasaan materi yang telah diajarkan oleh guru selama proses pembelajaran yang diukur melalui tes hasil belajar dengan menggunakan model pembelajaran circuit learning. Hasil belajar siswa pada penelitian ini setiap siklusnya mengalami peningkatan yang dapat digambarkan dalam tabel sebagai berikut

Tabel 1.Perbandingan Skor Hasil Belajar Pra Siklus, Siklus I dan Siklus II

\begin{tabular}{cccccccc}
\hline \multirow{2}{*}{ Nilai } & Kategori & \multicolumn{2}{c}{ Pra Siklus } & \multicolumn{2}{c}{ Siklus I } & \multicolumn{2}{c}{ Siklus II } \\
\cline { 3 - 8 } & $\begin{array}{c}\text { Jml. } \\
\text { Siswa }\end{array}$ & $\%$ & $\begin{array}{c}\text { Jml. } \\
\text { Siswa }\end{array}$ & $\%$ & $\begin{array}{c}\text { Jml. } \\
\text { Siswa }\end{array}$ & $\%$ \\
\hline $86-100$ & Baik Sekali & 0 & $0 \%$ & 0 & $0 \%$ & 6 & $37 \%$ \\
\hline $70-85$ & Baik & 0 & $0 \%$ & 1 & $6 \%$ & 7 & $44 \%$ \\
\hline $55-69$ & Cukup & 1 & $7 \%$ & 4 & $25 \%$ & 3 & $19 \%$ \\
\hline$<54$ & Kurang & 15 & $93 \%$ & 11 & $69 \%$ & 0 & $0 \%$ \\
\hline
\end{tabular}

Tabel 1 tersebut menunjukkan apa yang dilakukan peneliti pada penggunaan model pembelajaran circuit learning pada mata pelajaran IPS 
kelas V MI Wonoyoso Pringapus Kabupaten Semarang tahun 2017/2018 telah meningkatkan hasil belajar siswa atau menjadikan siswa mampu memahami materi yang diajarkan. Peningkatan hasil belajar siswa yang dapat dilihat dari setiap siklus yang dilakukan peneliti menunjukkan peningkatan secara signifikan.

b. Keaktifan Belajar

Pelaksanaan pembelajaran sangat berpengaruh terhadap penentuan hasil belajar siswa. Pelaksanaan penelitian dilakukan dengan menitik beratkan pada partisipasi siswa saat pembelajaran berlangsung. Aktivitas siswa dalam pembelajaran berpengaruh terhadap hasil belajar. Keaktifan siswa dapat terwujud jika siswa terlibat langsung dalam pembelajaran dengan bantuan guru sebagai fasilitator. Keaktifan siswa akan berpengaruh pada pemahaman siswa terhadap materi yang dipelajari. Penelitian ini meneliti keaktifan dari siswa, keaktifan siswa pada setiap siklusnya mengalami kenaikan. Kenaikan tersebut dapat digambarkan dalam tabel berikut ini:

Tabel 2. Perbandingan keaktifan Belajar Persiklus

\begin{tabular}{cccccccc}
\hline & & \multicolumn{2}{c}{ Pra Siklus } & \multicolumn{2}{c}{ Siklus I } & \multicolumn{2}{c}{ Siklus II } \\
\cline { 3 - 8 } Skor & Kategori & $\begin{array}{c}\text { Jml. } \\
\text { Siswa }\end{array}$ & $\%$ & $\begin{array}{c}\text { Jml. } \\
\text { siswa }\end{array}$ & $\%$ & $\begin{array}{c}\text { Jml. } \\
\text { Siswa }\end{array}$ & $\%$ \\
\hline $15-20$ & Aktif sekali & 1 & $6 \%$ & 2 & $12 \%$ & 14 & $88 \%$ \\
\hline $12-14$ & Aktif & 0 & $0 \%$ & 11 & $69 \%$ & 2 & $12 \%$ \\
\hline $7-11$ & Cukup & 15 & $94 \%$ & 3 & $19 \%$ & 0 & $0 \%$ \\
\hline $1-6$ & Kurang & 0 & $0 \%$ & 0 & $0 \%$ & 0 & $0 \%$ \\
\hline
\end{tabular}

Berdasarkan refleksi per siklus, pelaksanaan tindakan pada tiap siklus yang dilakukan oleh peneliti adalah baik. Tabel 4.2 di atas menunjukkan apa yang dilakukan guru untuk menjadikan siswa tertarik mengikuti pembelajaran dan terjadi pembelajaran yang berpedoman pada keaktifan siswa (student centered) bukan keaktifan guru (teacher 
centered). Keaktifan siswa mengikuti pembelajaran menjadi faktor penting dalam penerapan model circuit learning pada pembelajaran IPS kelas V MI Wonoyoso Pringapus. Siswa mengalami peningkatan keaktifan belajar dari tahap pra siklus hingga siklus II.

\section{Pembahasan}

Hasil belajar merupakan suatu angka yang telah berhasil diperoleh siswa dalam menuntaskan konsep-konsep mata pelajaran sesuai dengan kriteria ketuntasal minimal (KKM) yang telah ditetapkan sebelumnya dan disesuaikan dengan kurikulum yang berlaku. Melihat data keaktifan maupun hasil belajar siswa, dapat diketahui bahwa pembelajaran IPS dengan model pembelajaran circuit learning dapat meningkatkan keaktifan serta hasil belajar mata pelajaran IPS siswa kelas V MI Wonoyoso Pringapus. Indikator dari penelitian ini yaitu meningkatkan hasil belajar yang ditandai dengan rata-rata hasil belajar melebihi nilai KKM yaitu 70.

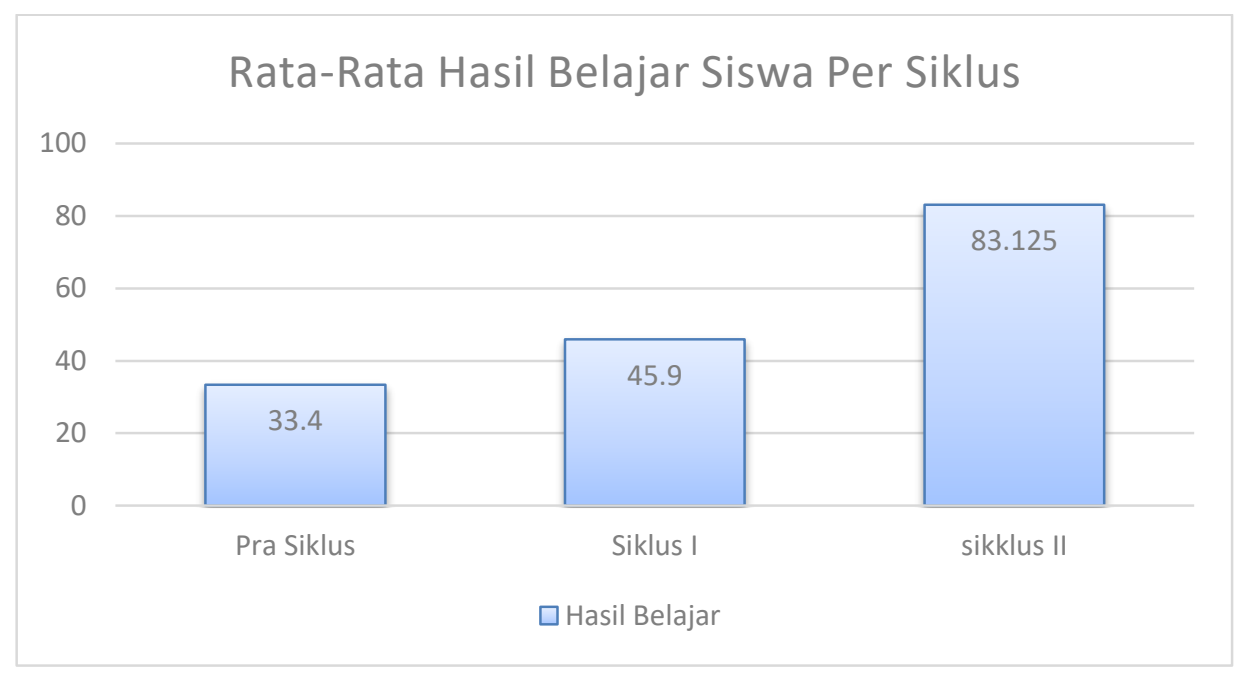

Gambar 2. Diagram Rata-rata hasil belajar Siswa persiklus 


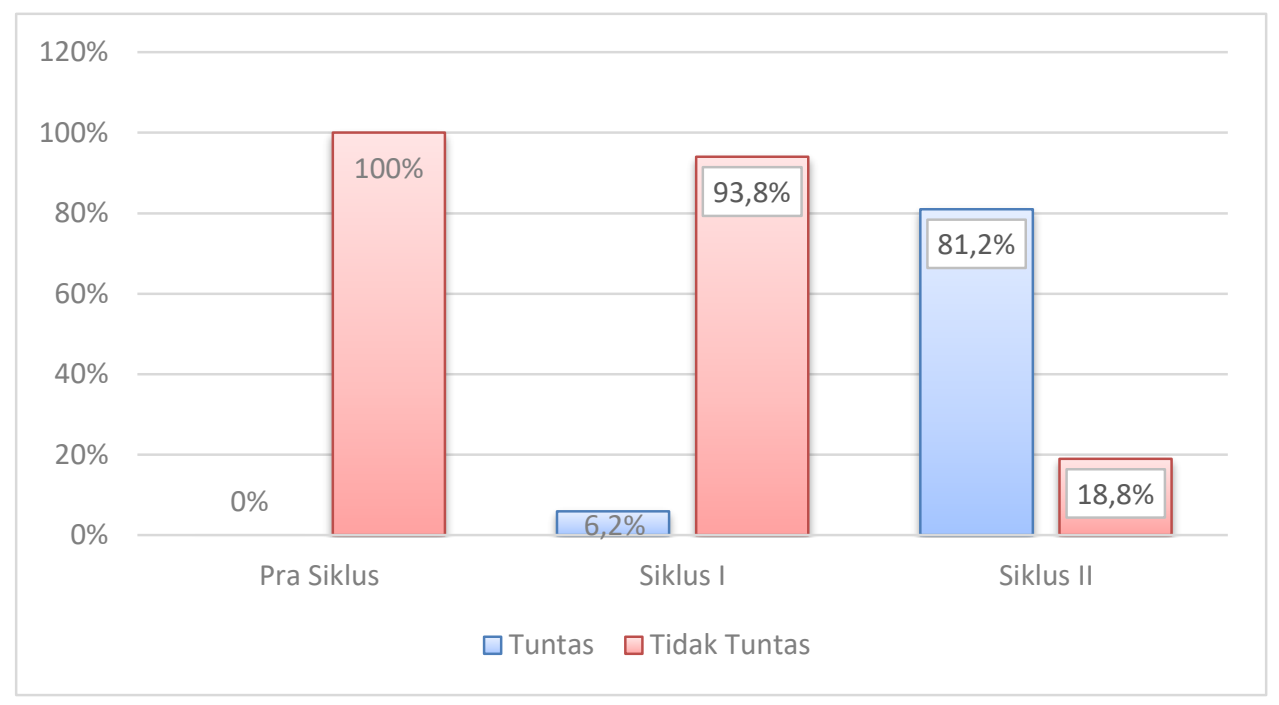

Gambar 3. Diagram Presentase Ketuntasan Klasikal Persiklus

Terlihat pada diagram batang pada gambar 2 dan 3 menyatakan bahwa tahap pra siklus nilai rata-rata yang diperoleh siswa sebesar 33,4 belum ada siswa yang mendapat nilai tuntas KKM, kemudian siklus I nilai rata-rata meningkat 45,9 dengan ketuntasan klasikal 6,2\% karena hanya 1 siswa yang tuntas mencapai nilai KKM (70), dan pada siklus II meningkat lagi menjadi 13 siswa yang tuntas, ketuntasan belajar yang mencapai 81,2\%, rata-rata hasil belajar siswa sebesar 83. Pencapaian tujuan pembelajaran dan hasil belajar terpenuhi pada siklus II, ketuntasan belajar yang mencapai $81,2 \%$ dari indikator keberhasilan yang ditetapkan peneliti yaitu $75 \%$.

Tabel 3. Rekapitulasi Hasil Belajar Siswa

\begin{tabular}{llccc}
\hline \multirow{2}{*}{ No } & \multirow{2}{*}{ Rincian Nilai Hasil Belajar } & \multicolumn{3}{c}{ Perolehan Nilai } \\
\cline { 3 - 5 } & & Pra siklus & Siklus I & Siklus II \\
\hline 1 & Jumlah Total Nilai & 535 & 735 & 1330 \\
\hline 2 & Nilai Rata-Rata & 33,4 & 45,9 & 83 \\
\hline 3 & Nilai Tertinggi & 65 & 80 & 100 \\
\hline
\end{tabular}




\begin{tabular}{clccc}
\hline 4 & Nilai Terendah & 15 & 20 & 55 \\
\hline 5 & Siswa Belum Tuntas & 16 & 15 & 3 \\
\hline 6 & $\begin{array}{l}\text { Presentase siswa yang } \\
\text { belum tuntas }\end{array}$ & $100 \%$ & $93,8 \%$ & $18,8 \%$ \\
\hline 7 & Siswa Tuntas & 0 & 1 & 13 \\
\hline 8 & $\begin{array}{l}\text { Presentase siswa yang } \\
\text { tuntas }\end{array}$ & $0 \%$ & $6,2 \%$ & $81,2 \%$ \\
\hline & Ketercapaian & $\begin{array}{c}\text { Belum } \\
\text { Tercapai }\end{array}$ & $\begin{array}{c}\text { Belum } \\
\text { Tercapai }\end{array}$ & Tercapai \\
\hline
\end{tabular}

\section{E. SIMPULAN}

Berdasarkan hasil penelitian yang dilakukan selama dua siklus, hasil pembahasan serta analisis maka dapat disimpulkan sebagai berikut:

1. Pembelajaran dengan model circuit learning pada mata pelajaran IPS kelas V MI Wonoyoso Pringapus tahun pelajaran 2017/2018 efektif dilaksanakan.

2. Peningkatan hasil belajar IPS siswa kelas V melalui model circuit learning meningkat lebih baik daripada pembelajaran sebelumnya, hal ini dibuktikan dengan adanya peningkatan nilai siswa setiap siklus. Tahap pra siklus nilai ratarata yang diperoleh siswa sebesar 33,4 belum ada siswa yang mendapat nilai tuntas KKM, kemudian siklus I nilai rata-rata meningkat 45,9 dengan ketuntasan klasikal 6,2\% karena hanya 1 siswa yang tuntas mencapai nilai KKM (70), dan pada siklus II meningkat lagi menjadi 13 siswa yang tuntas, ketuntasan belajar yang mencapai $81,2 \%$, rata-rata hasil belajar siswa sebesar 83,1, sehingga dengan model pembelajaran circuit learning mampu meningkatkan hasil belajar IPS siswa kelas V di MI Wonoyoso Pringapus tahun $2017 / 2018$ 


\section{DAFTAR PUSTAKA}

Agus, Moch. Krisno Budiyanto, Sintaks 45 Metode Pembelajaran dalam Student Centered Learning(SCL), Malang: Universitas Muhammadiyah Malang, 2016.

Shoimin, Aris, 68 Model Pembelajaran Inovatif dalam Kurikulum 2013, Yogyakarta: Ar-Ruzz Media, 2014.

Huda, Miftakhul, Model- Model Pengajaran Dan Pembelajaran, Yogyakarta: Pustaka Belajar, 2013.

Arikunto, Suharsimi dkk, Penelitian Tindakan Kelas, Jakarta: Bumi Aksara, 2010.

Puspa, Ayu, Dewi, Pengaruh Model Pembelajaran Circuit Learning Berbantu Media Audio Visual Terhadap Hasil Belajar IPSs siswa SD Negeri 1 Pejeng Tahun 2013/2014, Jurnal Mimbar PGSD Universitas Pendidikan Ganesha Jurusan PGSD, (vol :2 No: 1 tahun 2014).

Desmita, Psikologi Perkembangan Peserta Didik, Bandung: Remaja Rosydakarya, 2014.

Solihatin, Cooperative Learning Analisis Model Pembelajaran IPS, Jakarta: Bumi Aksara, 2005.

Alwi, Hasan. Kamus Besar Bahasa Indonesia, Jakarta: Gramedia Pustaka Utama, 2008. 